\title{
大腸癌検診の現状と課題 一便潜血検査の精度と偽陰性例の分析一
}

$\begin{array}{llll}\text { 山部 } & \text { 弘恵 } & \text { 三原 } & \text { 修一 } \\ \text { 浜田 } & \text { 幸生 } & \text { 牛島 } & \text { 由幾 } \\ \text { 森元 } & \text { 栄子 } & \text { 本藤 } & \text { 和子 }\end{array}$

我々は, 1987 年 4 月から, 日帰り人間ドックおよび 地域・職域集検において免疫便潜血検査 $(\mathrm{OC}$ へモディ ア）による大腸癌検診を行ってきた。今回,これまでの成 績を分析し,検診の精度と偽陰性例について検討した。

\section{成 績}

1) 1995 年 3 月までの延べ受診者数は 244,388 名, 要精検率 $4.1 \%$, 精検受診率 $70 \%$ で, 大腸ポリープ 1,528 例(発見率 $0.6 \%$ )，および大腸癌 208 例 (発見率 $0.09 \%)$ が発見され，140 例(67\%)が早期癌であった。

2 ) 日帰りドックでは 1990 年 11 月から, 地域集検 では 1992 年 4 月から二日法を行っており, 職域集検で は現在まで一日法を行っている。一日法延べ受診者数 は 191,956 名, 要精検率 $3.7 \%$, 精検受診率 $68 \%$ で, 大腸癌 131 例(発見率 $0.07 \%$ ) が発見され, 90 例 (69\%) が早期癌であった。一方二日法では，のべ受診者数 52,432 名, 要精検率 5.7\%, 精検受診率 77\% で，大腸 癌 77 例（発見率 $0.15 \%$ ）が発見され，50 例（65\%） が早期癌であった。要精検率は二日法が高率であった が，大腸癌発見率も二日法が 2 倍高率であった。

3 ) 大腸癌症例の検診および精検受診歴をみると, 一日法では 54 例 (41\%), 二日法では 25 例 (33\%)が逐年 検診発見癌であった。そのうち前年度の便潜血検査が陰 性であつた症例は一日法 40 例(全症例の $31 \%$ ) で 11 例 が進行癌であった。二日法では前年度の便潜血陰性癌 は 15 例(全症例の $20 \%$ )で, 5 例が進行癌であった。また 前年度の便潜血陽性例は一日法 14 例(全症例の 11\%) で，3 例は精検受診していたが癌は発見されておらず， 1 例が進行癌であった。精検未受診例は 11 例で 6 例が 進行癌であった。一方, 二日法では, 前年度の便潜血陽

\footnotetext{
Current Status and Problems of Mass Screening for Colorectal Cancer

-Diagnostic Accuracy of Fecal Occult Blood Test and the Analysis of False Negative Cases-

日本赤十字社熊本健康管理センター
}

\begin{tabular}{ll} 
河津佐和子 & \multicolumn{2}{l}{ 佐渡美智代 } \\
宮崎さおり & 野山 敦子 \\
小山 和作 &
\end{tabular}

性例は 10 例(全症例の 13\%) で, 6 例が精検受診してい たが癌は発見されておらず, 1 例が進行癌であった。また 4 例は精検未受診であったが,すべて早期癌であった。

4 ）便潜血陰性癌の部位は, 一日法・二日法とも直 腸および S 字状結腸が 70\%を占め, 次いで上行結腸が 多かった。便潜血陰性癌の大きさは $40 \%$ $10 \mathrm{~mm}$ 以 下, $29 \%$ が 11〜 $21 \mathrm{~mm}, 31 \%$ が $21 \mathrm{~mm}$ 以上であった。 便潜血陰性癌の進行度は, $53 \%$ が m, $19 \%$ が sm であっ たが, $28 \%$ が mp 以上の進行癌であった。53\%にポリぺ クトミーが，他は切除手術が施行された。

5 ）二日法で前年度の便潜血検査が陰性であった進 行癌 5 例は, 直腸が 3 例, $S$ 字状結腸 1 例, 上行結腸 1 例で, 4 例が $2 \mathrm{~cm}$ 以上の大きさであった。Dukes A が 3 例, Dukes C が 2 例であった。一方, 二日法で前年 度の便潜血検査が陽性であった 10 例のうち, 精検受診 していた 6 例中 5 例は $\mathrm{m}$ 癌でポリペクトミーにて治 癒していたが, 1 例は $\mathrm{S}$ 字状結腸の全周性の進行癌で, Dukes Cであった。前年度に, 注腸検査によって見逃 された癌であった。前年度精検末受診の 4 例はいずれ も $\mathrm{m}$ 癌であった。

6 ） 1993 年度の成績をもとに大腸癌検診の精度を 検討した。偽陰性例を逐年検診発見癌および検診後 1 年以内に判明した検診未発見癌とすると，一日法・二 日法それぞれの感度は $63 \% ・ 86 \%$, 特異度は $98 \%$ ・ $96 \%$ ，陽性反応適中度は $2.3 ・ 3.0$ であった。

\section{まとめ}

大腸癌検診の普及によって, 多くの救命可能癌の発 見が期待できる。しかし，検診の効果を高めるために はさまざまな課題を克服する必要がある。特に, 便潜 血検査陰性癌が高頻度に存在し, 進行癌も含まれるこ とから, 逐年検診を徹底することや将来的には内視鏡 の導入も必要かと思われる。また, 精検偽陰性癌対策 も重要であり, 精度の高い検査や十分な治療のできる 医療機関との連携が不可欠である。事後管理体制を充 実し, 精検受診率の向上を図ることも重要である。 